\title{
Principals' Technology Leadership and its Effect on Teachers' Technology Integration in 21st Century Classrooms
}

\section{Arumugam Raman}

Assoc. Prof., School of Education, Universiti Utara Malaysia, Malaysia, arumugam@uum.edu.my

\section{Raamani Thannimalai}

SMK Kepala Batas, Malaysia, raamani64@gmail.com

\section{Siti Noor Ismail}

Dr., School of Education, Universiti Utara Malaysia, Malaysia, siti.noor@uum.edu.my

This study aims to identify the effect of Principals' Technology Leadership on Teachers' Technology Integration in Malaysian secondary schools. This is a crosssectional survey where systematic random sampling was carried out to select 47 principals and 375 teachers from National Secondary Schools in the northern region of Kedah, Malaysia. Two questionnaires were used: Principals Technology Leadership Assessment (PTLA), which is based on the International Society for Technology in Education (ISTE)- Standards for Administrators (2014) was administered to principals, while the Learning with ICT: Measuring ICT Use in the Curriculum Instrument was administered to the teachers from the same schools as the principals. Descriptive analysis was carried out using SPSS Version 25, and SmartPLS was used for inferential analysis. Although the findings showed that the levels of Technology Leadership; the five constructs of ISTE (2014), and Teachers' Technology Integration were at high levels but, there was no significant relationship between Principals' Technology Leadership and Teachers' Technology Integration in the selected schools in the northern region of Kedah. Principals' preparatory programmes should emphasize leadership based on technology to enhance the integration of technology in classrooms. Further research on professional development for principals' is recommended.

Keywords: principals' technology leadership, teachers' technology integration, ISTE, ICT, SmartPLS

Citation: Raman, A., Thannimalai, R., \& Ismail, S. N. (2019). Principals' Technology Leadership and its Effect on Teachers' Technology Integration in 21st Century Classrooms. International Journal of Instruction, 12(4), 423-442. https://doi.org/10.29333/iji.2019.12428a 


\section{INTRODUCTION}

School principals' and teachers' must be prepared to face the Fourth Industrial Revolution and the challenges which come along with it. Furthermore, they must also continue to transform and develop educational organizations and its students who are digital natives (Battons, 2018). The IR 4.0 witnessed the Internet of Things (IoT) in almost all aspects of everyday life, and due to this, principal's leadership, teaching and learning practices in the classroom has to evolve in tandem with it (Schwab, 2018). Thus, in an environment where hologram technology, social media and artificial intelligence need to be the preferred teaching tools, and which are more relevant for keeping up with 21st Century classroom pedagogy, school principals have to undertake imminent paradigm shifts pertaining to their roles that require them to become technology leaders so that they can spearhead the embracing of the inevitable and evertransforming digital era. Prevalent 21st-century priorities such as innovation and technology must be vigorously practised (Mullen, 2019).

Leadership being the key component in guiding the teaching-learning process is necessary for preparing today's students with relevant knowledge and skills as leaders play an integral role in technology integration (Gupta, 2018). Principals in Malaysia are required to transform and improve the performance and excellence of education as envisaged by the various government policies (MOE, 2012). The impending challenge in the Malaysian education system is to push or "propel" educators' towards the 21 st century teaching and learning pedagogy to enhance the quality of education in Malaysia. In addition, authoritative as well as assertive school principals are deemed necessary as they play an important role as Technology Leaders (Papa, 2011). In principle, they will be able to motivate teachers to adapt and exploit teaching pedagogy that is appropriate to the technology era. The Malaysian education system is currently in the second wave (2016-2020) of the Malaysian Education Blueprint (2013-2025) (MOE, 2012). Thus, school leaders in the 21st century have an important role in ensuring the integration of ICT (Information and Communication Technology) into teaching and learning pedagogy, as well as in their management and leadership.

The Education Ministry of Malaysia has spent more than RM600 million on implementing ICT in educational initiatives, such as the 1BestariNet School. This amount is one of the highest capital investments ever made in Malaysia's education system. The Auditor-General's Report 2013 Third Series (Ministry of Finance, 2014) on 1BestariNet's performance and management has found some weaknesses (National Audit Department, 2014). One of the weaknesses associated with this study is that "the use of Virtual Learning Environment (VLE) by teachers was very low, that is, between $0.57 \%$ and $4.69 \% "$ (Ministry of Finance, 2014, p.213. This shows a slow and low technology acceptance of ICT in classrooms. Given this, urgent steps need to be taken so that teachers receive and use technology to perform routine tasks. This finding also showed that the return on money invested in 1BestariNet was not as expected. This is in line with Jimenez, Nguyen, and Patrinos (2012), who suggested that Malaysia's education standard still needed to be improved and the Malaysian government needs to allocate more funds to produce quality modern education. 
Past research on Technology Leadership only used the ISTE-Standards for Administrators (2014) as a whole, to study the qualities of technology leaders in school (Alkrdem, 2014). Although there were studies that linked ISTE (2014) with other variables such as the acceptance and use of SMS (short messaging system) among teachers (UTAUT2) in Malaysia (Wei, Piaw, Kannan \& Moulod, 2016), not many studies focussed the relationship between the five constructs found in ISTE -Standards for Administrators (2014) with Technology Integration in high schools. Also, Metcalf (2012) found that ISTE-Standards for Administrators were poorly researched in western countries and suggested that a detailed study should be carried out. In this regard, Metcalf (2012) suggested that the focus of the research should be on the digital aspect of digital citizenship (one of the constructs found in ISTE (2014).

Realising the importance of Technology leadership among school principals, this research studied the levels of Technology Leadership; the five constructs of the International Society for Technology in Education (ISTE)-Standards for Administrators (2014) and Teachers' Technology Integration in selected schools in the northern region of Kedah, Malaysia.

\section{LITERATURE REVIEW}

In the past three decades, previous research has proven that knowledge and skills in technology have been pivotal in school leadership. According to Senge (1990), school principals need to be imaginative and courageous to become technology leaders. Moreover, only the school principal has the power to make instructional decisions on technology infrastructure and programmes in school (Papa, 2011). Furthermore, technology leadership amongst school principal is crucial to increase technology literacy and technology integration in the classroom among teachers (Chang, 2012).

In the Malaysian context, school principals and teachers should be prepared to respond to transformations of the 21 st century by equipping themselves with Information Technology and Communication (ICT) skills in order to pursue the seventh shift of the Malaysian Education Blueprint (PPPM, 2013-2025) (MOE, 2012), which is Utilizing ICT for Improving the Quality of Learning. Also, the need for ICT to be integrated into learning and facilitating processes; management and administration of schools have been emphasized in government policies such as the Interim Strategic Plan, 2011-2020 (MOE, 2012). Additionally, the National Education Policy (MOE, 2012) (Third Edition, pages 42-45) provided by the Education Policy Planning and Research Division (MOE, 2012) clarified the need for the Malaysian Education system to integrate ICT into teaching and management processes. Principals as technology leaders and teachers' of national secondary schools must be skilled and knowledgeable to be able to implement 21 st century education in classrooms (Roblyer \& Doering, 2014). The technology leadership of principals and the readiness of teachers to embrace and integrate ICT will enable the education system of Malaysia to be in sync with government policies.

The use of ICT in schools is still not satisfactory, in terms of both quality and quantity. The gap between high spending on educational technology and expected returns on 
school improvement is a widely debated global educational agenda (Leong, 2010; Lu, 2013; Wahdain \& Ahmad, 2014). While on-going efforts are being undertaken to enhance the skills of Malaysian ICT teachers (Wei, Piaw \& Kannan, 2017), the integration of ICT in schools has not reached the level of satisfaction (Fong, Ch'ng \& Por, 2013).

Thus, the Ministry of Education of Malaysia will upgrade its existing training programme to ensure that all teachers have at least the minimum level of ICT literacy by 2025, which is also in line with the aspirations of the Malaysia Education Blueprint (2013-2025). The required standard of ICT literacy for Malaysian administrators and teachers is based on the ICT competency rubric developed by the International Association of Educational Technologies (IAET) (MOE, 2013). All trainee teachers are required to achieve competency standards as part of their prerogative training. Tests and training processes will be developed and supported through a professional development team operated through 1 BestariNet.

In addition, Harrison, Comber, Fisher, Haw, Lewin, Lunzer, et al., (2002) and Hennessy, Ruthven, and Brindley (2005) described that the lack of ICT usage might be due to lack of confidence in the use of ICT and lack of support for teachers. Further, studies show that professional development is among the most critical factors for improving students' learning through ICT integration (Ringstaff \& Kelley, 2002; Solomon, 1995). Aside from this, a study conducted by UNESCO in 2012 found that the use of ICT by teachers in schools was limited to the use of word processing applications as a teaching tool (MOE, 2012). Thus, the implication of the results of the above studies is that effective and concerted efforts for staff development programmes at secondary schools in Malaysia is a great necessity and this case scenario indeed reflects that school principals' or the school leadership need to be highly proactive, discretionary and assertive.

Past studies have also shown that leadership is closely linked to the effectiveness of complex organizational functions (Marzano, Waters \& McNulty, 2005). Similarly, Byrom and Bingham (2001) concluded that the lack of leadership and trained administrators are two of the main reasons for the failure to integrate technology into education. Additionally, this study is supported by Ford (2000), Gibson (2001) who proved that technology could be successfully implemented in the classroom if there is a contribution from quality leadership.

Approached in these terms, Brockmeier, Sermon and Hope (2005) identified that the role of the principal as a technology leader in the integration of technology at schools could have a significant influence on the level of technology utilization during the teaching and learning process. Research on leadership principals' technology is lacking in existing literacy bases (Albion, 2006; Davies, 2010; McLeod \& Richardson, 2011; Richardson, Bathon, Flora \& Lewis, 2012). Therefore, this study was conducted to demonstrate that principals' leadership in schools has a positive relationship to the integration of technology in schools. 
The NETS-A is a guideline for school principals to understand their role as a technology leader so that they can accomplish technology integration in the educational process (Sincar, 2013). Over the last three decades, NETS-A, as a whole was used in research to study the effect of principals' technology leadership on teachers' technology integration but did not investigate the effect of its constructs (Alkrdem, 2014). ISTE has since renamed the NETS-A to ISTE Standards for Administrators (2014) (Esplin, 2017). Although there was a study linking ISTE- Standards for Administrators (2014) with other variables such as receiving and using SMS by teachers (UTAUT2) (Wei, Piaw, Kannan \& Shafinaz A. Moulod, 2016), no other study in Malaysia researched the relationship of the five constructs of ISTE-Standards for Administrators (2014) with technology integration in secondary schools. Metcalf (2012) proved that studies using NETS-A standards, were very poorly conducted in western countries and suggested further studies on Digital Citizenship, which is one of the NETS-A (2009) constructs.

This research was based on current issues related to technology leadership models as suggested by Anderson and Dexter (2005); Davies (2010); Haynes, Arafeh, and McDaniels (2014) and the technology integration model suggested by Flanagan and Jacobsen (2003). This research also provided a contextual framework with which school principals can undertake responsibilities as technology leaders and to mentor teachers to integrate ICT in the classroom.

\section{Research Questions}

Based on the discussion above, the research questions of this study are:

i. What is the level of Principals' Technology Leadership at National Secondary Schools?

ii. What is the level of Teachers' Technology Integration at National Secondary Schools?

iii. Do the constructs of Principals' Technology Leadership (Visionary Leadership, Digital Age Learning Culture, Excellence in Professional Practice, Systemic Improvement, and Digital Citizenship) affect Teachers' Technology Integration in National Secondary Schools?

\section{Conceptual Framework}

Figure 1 shows the proposed model for this study. Principals' Technology Leadership and the five constructs of Technology Leadership which are Visionary Leadership, Digital Age Learning Culture, and Excellence in Professional Practice, Systemic Improvement and Digital Citizenship are independent variables; and Teachers' Technology Integration is a dependent variable. 


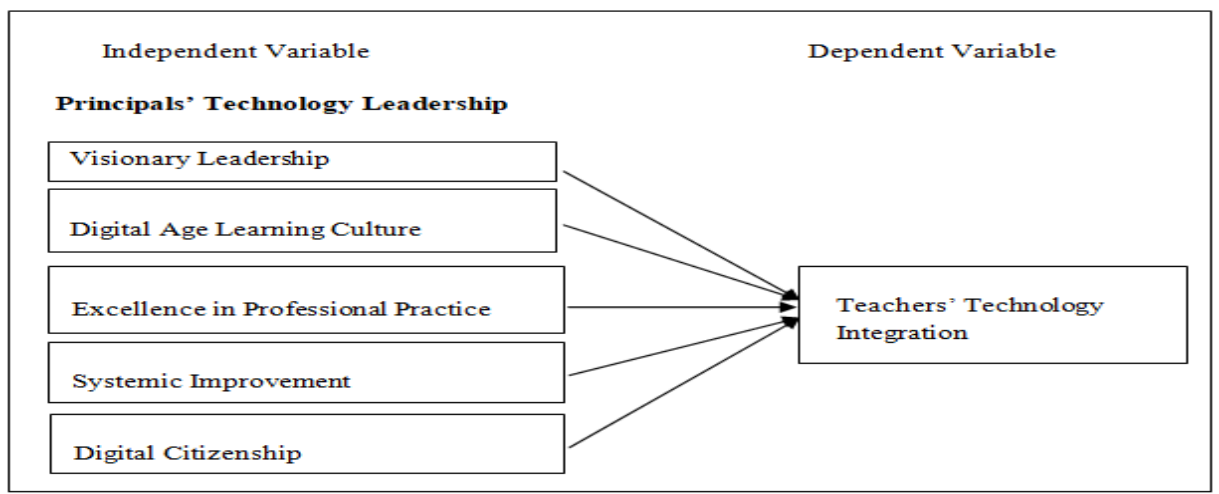

Figure 1

Conceptual Framework

\section{METHOD}

This was non-experimental descriptive research using a cross-sectional survey design. Since this was a quantitative method, questionnaires were used to answer all research questions. This study empirically measured the level of technological leadership as well as its effect on the integration of technology in the classroom by the teacher. The numerical data generated were analysed using inferential statistics. This study was correlation by nature. In this study, Principals' Technology Leadership which consisted of five constructs, were independent variables and Teachers' Technology Integration was a dependent variable. Along with that, it was reviewed whether there was a relationship between Principals Technology Leadership and Teachers' Technology Integration.

\section{Population and Sampling}

Principals and teachers were chosen from 47 National Secondary Schools in the northern region of Kedah which consists of five districts namely, Kota Setar, Kubang Pasu, Langkawi, Padang Terap and Pendang (according to the District Education Offices). Systematic random sampling was carried out to select 47 principals and 375 teachers. Table 1 shows the distribution of schools in each district. Each school is headed by a principal. Principals are considered homogeneous as they are appointed according to specifications from the Ministry of Education Malaysia. The total number of teachers who responded to the survey was 375 .

Table 1

Distribution of Respondents.

\begin{tabular}{lll}
\hline District & Principals & Teachers \\
\hline Kota Setar & 26 & 205 \\
Langkawi & 2 & 21 \\
Kubang Pasu & 9 & 68 \\
Padang Terap & 4 & 25 \\
Pendang & 4 & 56 \\
Total & 47 & 375 \\
\hline
\end{tabular}




\section{Instrumentation}

Two instruments were used in this research. The first instrument was for school principal: Principals' Technology Leadership Assessment (PTLA) which was modified from International Society for Technology in Education-Standards for Administrators (ISTE, 2014). The ISTE (2014) was modified according to the Malaysian culture and was verified by experts in the field. The second instrument,which was for teachers, aimed to measure Teachers' Technology Integration. This instrument was modified from the Learning with ICT: Measuring ICT Use in the Curriculum Instrument (Jamieson, Watson \& Finger, 2003, Jamieson-Proctor, Watson, Finger \& Grimbeek, 2005 and Jamieson, Finger \& Albion, 2010). Both instruments were translated from English to Malay which is the national language. Back-translation was carried out to make sure the meaning of the items remained the same after translation (Brislin, 1980).

\section{Survey Reliability and Validity}

Two experts in the field of this research certified the content validity of both the instruments. A pilot study that used both these instruments was carried out, and both the instruments were found to be valid and reliable. The reliability of the PTLA was very high with Cronbach's alpha $(\alpha)=0.93$ and Learning with ICT: Measuring ICT Use I the Curriculum Instrument also had a very high reliability of Cronbach's alpha $(\alpha)=0.94$.

\section{Data Analysis}

The quantitative data collected were analyzed using two statistical software: (i) SPSS, Statistical Package for the Social Sciences (SPSS) Version 25.0 and (ii) SmartPLS (Structural Equation Modeling - Partial Least Squares).

\section{FINDINGS}

\section{Principals' Demography}

Descriptive studies were carried out on the real sample involving 47 principals using SPSS version 25. Table 2 shows the percentage and frequencies of the principals in this study.

Table 2

Profile of Principals

\begin{tabular}{lll}
\hline Variables & Frequency(n) & Percentage $(\%)$ \\
\hline Gender & 29 & 61.7 \\
Male & 18 & 38.3 \\
Female & & \\
\hline Age & 2 & 4.3 \\
Less than 45 years & 45 & 95.7 \\
More than 45 years & & \\
\hline Experience as Principal & 9 & 19.1 \\
Less than one year & 34 & 72.3 \\
2-10 years & 3 & 6.4 \\
11-20 years & 1 & 2.1 \\
More than 21 years & & \\
\hline
\end{tabular}

From the descriptive study, it was found that $29(61.7 \%)$ of the principals were male compared to $18(38.3 \%)$ who were female. A total of 45 principals were more than 45 years' of age $(95.7 \%)$, compared to two of them $(4.3 \%)$ who were less than 45 years old. 
In addition, 34 of the principals had 2 to 10 years of experience $(72.3 \%)$, followed by nine of them who had experience of less than a year (19.1\%); three of them had 11-20 years of experience $(6.4 \%)$, and only one of the principals had more than 21 years of experience $(2.1 \%)$.

\section{Principal's technology leadership level in schools}

The mean and standard deviations for Principals' Technology Leadership and its construct are shown in Table 4. According to Moidunny (2009), the mean score interpretation is as shown in Table 3.

Table 3

Mean Score Interpretation

\begin{tabular}{ll}
\hline Mean Score & Interpretation \\
\hline $1.00-1.80$ & Very Low \\
$1.81-2.60$ & Low \\
$2.61-3.20$ & Medium \\
$3.21-4.20$ & High \\
$4.21-5.00$ & Very High \\
\hline
\end{tabular}

Source: Moidunny (2009)

The findings revealed (Table 4) that Principals' Technology Leadership and its five constructs showed a high mean level at National Secondary Schools in the northern region of Kedah. Overall, Principals' Technology leadership had a mean of 4.05 and $\mathrm{SD}=.44$.

Table 4

Descriptive Analysis of Technology Leadership and Its Constructs

\begin{tabular}{llll}
\hline Constructs & Mean & $\begin{array}{l}\text { Standard } \\
\text { Deviation }\end{array}$ & $\begin{array}{l}\text { Level of } \\
\text { Technology Leadership }\end{array}$ \\
\hline Technology Leadership (Overall) & 4.05 & .44 & High \\
Visionary Leadership & 3.97 & .57 & High \\
Digital Age Learning Culture & 3.90 & .55 & High \\
Excellence in Professional Practice & 4.06 & .51 & High \\
Systemic Improvement & 4.17 & .44 & High \\
Digital Citizenship & 4.13 & .50 & High \\
\hline
\end{tabular}

Table 4 also revealed that the Systemic Improvement construct has the highest mean $(\bar{X}=4.17, \mathrm{SD}=.54)$ followed by Digital citizenship $(\bar{X}=4.13, \mathrm{SD}=.50)$; Excellence in Professional Practice $(\bar{X}=4.06, \mathrm{SD}=.1)$; Visionary Leadership $(\bar{X}=3.97, \mathrm{SD}=.74)$; and the lowest is Digital Age Learning Culture construct which has the lowest $(\bar{X}=4.13, \mathrm{SD}=.54)$.

\section{The Level of Teachers' Technology Integration in National Secondary Schools}

Descriptive analysis was carried out to examine the level of Technology Integration among 375 teachers at 47 National Secondary schools in Kedah. Based on Table 5, it was found that the mean value and the deviation of Teachers' Technology Integration (PT) were $(\bar{X}=3.62, \mathrm{SD}=.70)$. It can be concluded that the mean score for the Teachers' Technology Integration (PT) was at a high level. 
Table 5

Teachers Technology Integration

\begin{tabular}{lllll}
\hline Variable & $\begin{array}{l}\text { No. of } \\
\text { items }\end{array}$ & Mean & $\begin{array}{l}\text { Standard } \\
\text { Deviation }\end{array}$ & $\begin{array}{l}\text { Level of Teachers' } \\
\text { Technology Integration }\end{array}$ \\
\hline Teachers Technology Integration & 20 & 3.62 & .70 & High \\
\hline
\end{tabular}

\section{Measurement Model Evaluation}

The measurement model in this study was reflective. Reflective measurement model evaluation can be implemented through three procedures as follows:

i. Determine the reliability of constructs through internal consistency reliability such as Cronbach's alpha value and Composite Reliability value (Chin et al., 2010, 2017).

ii. Evaluate the convergent validity involving the value of the Average Variance Extracted (AVE) and the external loading value (Hair et al., 2017).

iii. Determine the Discriminant Validity which involves two criteria namely (a) Cross-loading Value and (b) Fornell-Larcker.

\section{Construct Reliability and Convergent Validity Evaluation}

The reliability of the constructs in this study was assessed through the internal consistency value of each involved construct. It is done through calculations of PLS Algorithm (Hair et al., 2017). In the early stages of converging reliability and convergence credibility, it was found that this study model did not comply with the cut off value.

In that regard, some external loading that has been identified under the permissible value limit below the value of 0.5 were deleted. This was done after taking into consideration Chin (1998), Hair et al. (2010) and Nunnaly (1978) who indicated that the value of 0.5 to 0.6 is considered to be sufficient to test the Discrimination Validity. The indicator which were deleted in the research model were six items (outer loading) namely KP1 ($0.088)$ and KP3 (-0.007) for the construct of Proficiency in Professional Practice (PP). For the Teachers' Technology Integration (PT) construct, the items that were deleted were PT2 (0.268), PT19 (0.455) and PT21 (0.494).

After deleting the items, the researchers once again evaluated the measurement model using PLS Algorithm. The PLS Algorithm calculation found that Construct Reliability evaluation based on Cronbach's alpha was beyond the recommended value by Robinson, Shaver and Wrightsman (1991), which is above 0.70. Meanwhile, based on the Composite Reliability Value, it also showed that the value obtained was above 0.70 , which meets the acceptance limit values proposed by Hair et al. (2017). This means that the model of this study has achieved Internal Consistency Values. These values are reported in Table 5 .

Next, to determine convergence validity in the study model, the value of outer loading for each item was determined. The external loading value of each item in the study model was above 0.50. According to Hair et al. (2017) if the external loading value exceeds 0.50 , then it is said to have Convergent Validity. Furthermore, the Average Variance Extracted (AVE) value obtained was above 0.5 (Hair et al., 2010; 2017). 
Assessment of Discrimination Validity was done through cross-loading evaluation by comparing the value of outer loading (bolded item) with cross-loading value. According to Chin (1998), Discrimination Validity is achieved when the outer loading tested exceeds its cross-loading value. Table 6 shows the cross-loading value in the study model. Also, discriminant validity is assessed using Fornell and Larcker criteria (Hair et al., 2010; 2017) by comparing the value of the correlation between constructs with AVE square root (bold values). After comparing the value as in Table 6, it was found that the AVE square root is greater than the value of the correlation between the constructs. This means that the legitimacy of the discriminant requirement based on Fornell-Larcker criteria was achieved in this study (Hair et al., 2010; 2017).

Table 6

Cronbach's alpha Value, Composite Reliability, Average Variance Extracted (AVE) and Convergent Validity

\begin{tabular}{|c|c|c|c|c|c|}
\hline Construct & Indicator & OL & $\mathrm{CR}$ & AVE & $\mathrm{CV}, \mathrm{AVE}>0.5$ \\
\hline \multirow[t]{5}{*}{ Digital Age Learning Culture (BP) } & $\mathrm{BP} 1$ & 0.875 & 0.882 & 0.60 & Yes \\
\hline & BP2 & 0.855 & & & \\
\hline & BP3 & 0.658 & & & \\
\hline & BP4 & 0.742 & & & \\
\hline & BP5 & 0.725 & & & \\
\hline \multirow[t]{4}{*}{ Digital Citizenship (KD) } & KD1 & 0.873 & 0.878 & 0.64 & Yes \\
\hline & KD2 & 0.823 & & & \\
\hline & KD3 & 0.717 & & & \\
\hline & KD4 & 0.781 & & & \\
\hline \multirow[t]{2}{*}{$\begin{array}{l}\text { Excellence in Professional Practice } \\
\text { (KP) }\end{array}$} & KP2 & 0.803 & 0.895 & 0.81 & Yes \\
\hline & KP4 & 0.966 & & & \\
\hline \multirow[t]{2}{*}{ Visionary Leadership (KV) } & KV1 & 0.832 & 0.858 & 0.75 & Yes \\
\hline & KV2 & 0.899 & & & \\
\hline \multirow[t]{5}{*}{ Systemic Improvements (PS) } & PS1 & 0.677 & 0.857 & 0.54 & Yes \\
\hline & PS2 & 0.686 & & & \\
\hline & PS3 & 0.652 & & & \\
\hline & PS4 & 0.838 & & & \\
\hline & PS5 & 0.826 & & & \\
\hline \multirow[t]{10}{*}{ Teachers' Technology Integration (PT) } & PT10 & 0.648 & 0.975 & 0.96 & Yes \\
\hline & PT11 & 0.851 & & & \\
\hline & PT12 & 0.874 & & & \\
\hline & PT13 & 0.765 & & & \\
\hline & PT15 & 0.846 & & & \\
\hline & PT16 & 0.811 & & & \\
\hline & PT17 & 0.628 & & & \\
\hline & PT18 & 0.839 & & & \\
\hline & PT20 & 0.724 & & & \\
\hline & PT3 & 0.742 & & & \\
\hline \multirow[t]{6}{*}{ Teachers' Technology Integration (PT) } & PT4 & 0.883 & 0.966 & 0.64 & Yes \\
\hline & PT5 & 0.627 & & & \\
\hline & PT6 & 0.864 & & & \\
\hline & PT7 & 0.856 & & & \\
\hline & PT8 & 0.867 & & & \\
\hline & PT9 & 0.909 & & & \\
\hline
\end{tabular}


Loadings, $\mathrm{CA}=$ Cronbach's alpha, $\mathrm{CR}=$ Composite Reliability, AVE $=$ Average Variance Extracted, $\mathrm{CV}=$ Convergent Validity.

Table 7

Fornell dan Larcker Criteria

\begin{tabular}{ccccccc}
\hline Contruct & BP & KD & KP & KV & PS & PT \\
\hline BP & $\mathbf{0 . 7 7 5}$ & & & & & \\
KD & 0.491 & $\mathbf{0 . 8 0 2}$ & & & & \\
KP & 0.538 & 0.715 & $\mathbf{0 . 9 0 0}$ & & & \\
KV & 0.780 & 0.565 & 0.578 & $\mathbf{0 . 8 6 7}$ & & \\
PS & 0.603 & 0.741 & 0.683 & 0.584 & $\mathbf{0 . 7 4 0}$ & \\
PT & 0.294 & 0.276 & 0.230 & 0.389 & 0.351 & $\mathbf{0 . 8 0 1}$ \\
\hline
\end{tabular}

Note $. \mathrm{BP}=$ Digital Age Learning Culture; $\mathrm{KD}=$ Digital Citizenship; KP =Excellence in Professional Practice $\mathrm{KV}=$ Visionary Leadership; PS =Systemic Improvement; PT =Teachers' Technology Integration

\section{Assessment Summary of Graphic Measurement Model}

A Graphic Measurement Model Assessment procedure using Smart PLS was conducted. The summary of the assessment of the measurement model is shown in Figure 2. Furthermore, the data was analyzed to produce a Graphic Measurement Model to see the effects of independent variables (IV) on dependent variables (DV) and output results such as Factor Loadings Coefficient. The blue circles in Figure 2 refer to the variables. Whereas, the value in the circle refers to the value of Average Variance Extracted (AVE). The value that lies in the line that connects between the variables refers to Path Coefficient value. The yellow boxes refer to the items in the questionnaire. Meanwhile, the value above the line that connects the variables and the items are known as the Outer Loading value or Item Loading value. The values in Figure 2 are the values discussed in Table 6.

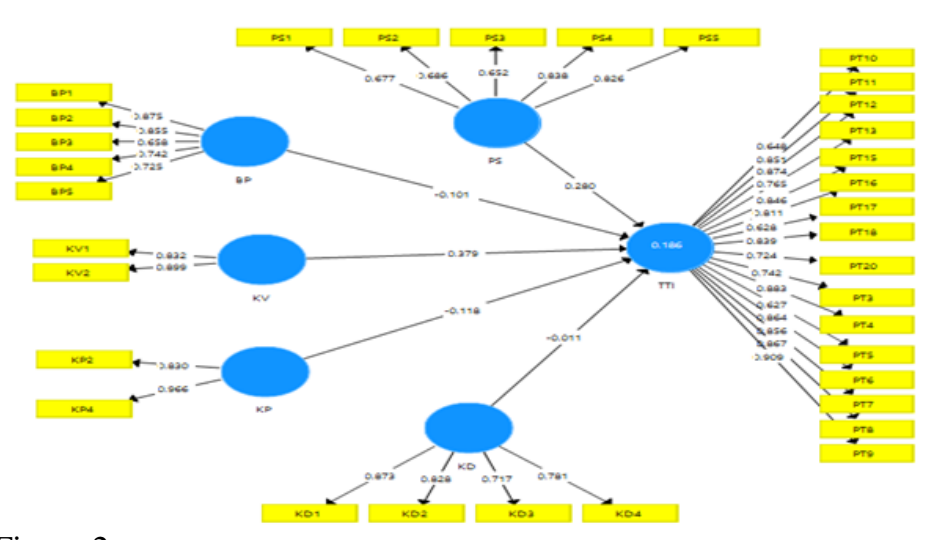

Figure 2

Measurement Model Evaluation

\section{Measurement Model Evaluation}

In order to continue the evaluation of the structural model, bootstrapping procedure with a total of 5000 subsamples was used. The test type used was in the form of one-tailed 
and significant level is 0.05 (Hair, Hult, Ringle \& Sarstedt, 2017). In this study, the test type used was one-tailed because the research question had a direction that was predicted that is: independent variables would have a positive effect on the dependent variable. Before the evaluation of the structural model, the value of the study model was assessed.

\section{Partial least squares}

Path analysis was carried out to test the direct relationship between the variables used in the study model (Hair et al., 2017; Henseler, Ringle, \& Sinkovics, 2009). Also, according to Hair et al. (2017) hypothesis testing $1\left(\mathrm{H}_{1} 1\right)$ in this study could be done through testing of hypothesis $2\left(\mathrm{H}_{1} 2\right)$ to hypothesis $6\left(\mathrm{H}_{1} 6\right)$. This is because the perception of the relationship between Principal Technology Leadership (KT) can be carried out through the assessment of the independent variables (constructs) that fall under the Principals' Technology Leadership (KT) variables which are, the Visionary Leadership, Digital Age Learning Culture, Digital Citizenship, Excellence in Professional Practice and Systemic Improvement. Table 8 shows the Structural Model Evaluation result (Direct Effect).

Table 8

Structural Model Evaluation Result (Direct Effect)

\begin{tabular}{lllllll}
\hline No. & Hypothesis & Coefficient $(\beta)$ & SD & $t$ Value & $p$ value & Result \\
\hline $\mathrm{H}_{1} 1$ & KV $\rightarrow$ PT & 0.370 & 0.246 & 1.539 & 0.124 & Non-Significant \\
$\mathrm{H}_{1} 2$ & BP $\rightarrow$ PT & -0.101 & 0.300 & 0.338 & 0.736 & Non-Significant \\
$\mathrm{H}_{1} 3$ & KP $\rightarrow$ PT & -0.118 & 0.340 & 0.346 & 0.730 & Non-Significant \\
$\mathrm{H}_{1} 4$ & PS $\rightarrow$ PT & 0.280 & 0.234 & 1.195 & 0.233 & Non-Significant \\
$\mathrm{H}_{1} 5$ & KD $\rightarrow$ PT & -0.011 & 0.300 & 0.037 & 0.970 & Non-Significant
\end{tabular}

Note. $\mathrm{SD}=$ Standard Deviation, $\mathrm{BP}=$ Digital Age Learning Culture; $\mathrm{KD}=$ Digital Citizenship; KP $=$ Excellence in Professional Practice; $\mathrm{KV}=$ Visionary Leadership; PS =Systemic Improvement; PT $=$ Teachers' Technology Integration

\section{Coefficient Determination}

The main criterion used to evaluate the structural model was the value of the determination coefficient (R2) (Hair et al., 2017; Henseler et al., 2009). The value of the coefficient of determination (R2) represents the proportion of variance in dependent variables that can explain predictor (predictor variables) (Elliott \& Woodward, 2007). The value of the determination coefficient (R2) for the Teacher's Technology Integration (PT) variable is as in Table 9.

Table 9

Coefficient Assessment Determination, $\mathrm{R}^{2}$

\begin{tabular}{ll}
\hline Variable & $R^{2}$ Value \\
\hline Teachers' Technology Integration (PT) & 0.186 \\
\hline
\end{tabular}

According to Hair et al. (2017), the value of the Determination Coefficient $\left(\mathrm{R}^{2}\right)$, depends on the context of the research conducted by the researcher. It is judged on the 
basis of (i) Chin (1998) that the R2 value of 0.186 gives a weak influence, 0.33 gives a moderate influence and 0.75 gives a strong influence and (ii) Hair et al. (2017) stated that the value of $\mathrm{R}^{2} 0.25$ was weak, 0.50 as moderate and 0.75 was strong. Therefore, the greater the value of the Determination Coefficient $\left(\mathrm{R}^{2}\right)$ the greater the proportion of variance and the better the relationship between the variables tested (Gotz, LiehrGobbers \& Krafft, 2010).

This study found that the value of the Determination Coefficient (R2) for Teachers' Technology Integration variable (PT) was 0.186 . Thus, it can be explained that 18.6 per cent of the variance in the Teachers' Technology Integration variable (PT) can be explained by the constructs Visionary Leadership (KV), Digital Age Learning Culture (BP), Excellence in Professional Practice (KP), Systemic Improvement (PS) and Digital Citizenship (KD). Also, the value of the Determination Coefficient (R2) obtained illustrated that the variable of Teachers' Technology Integration (PT) had a very small effect. Nevertheless, the value of the Determination Coefficient (R2) of 0.186 remained above the minimum required value of at least 0.100 as stated by Falk and Miller (1992).

\section{Evaluation of Effect Size}

The effect size (f2) is the relative effect of independent variables on dependent variables through changes that occur in the value of the Determination Coefficient $\left(R^{2}\right)$ (Chin, 1998). Hair et al. (2017) suggested the scale size determination (f2) as follows (i) 0.35 (big effect), (ii) 0.15 (moderate effect) and (iii) 0.02 (small effect).

Table 10

Effect Size Evaluation, $\mathrm{f}^{2}$

\begin{tabular}{ll}
\hline Constructs & Teachers' Technology Integration (PT) \\
\hline Digital Age Learning Culture (BP) & 0.004 \\
Digital Citizenship (KD) & 0.000 \\
Excellence in Professional Practice & \\
(KP) & 0.007 \\
Visionary Leadership (KV) & 0.060 \\
Systemic Improvement (PS) & 0.034
\end{tabular}

Note . BP = Digital Age Learning Culture; KD = Digital Citizenship; KP =Excellence in Professional Practice; KV =Visionary Leadership; PS =Systemic Improvement; PT =Teachers' Technology Integration

Based on Table 10, the effect size (f2), for Digital Age Learning Culture (BP) on Teachers' Technology Integration (PT) was 0.004 (small effect); the effect size (f2), for Digital Citizenship (KD) on Teachers' Technology Integration (PT) was 0.000 (no effect); the effect size (f2), for Excellence In Professional Practice (KP) on the Teachers Technology Integration (PT) was 0.007 (small effect); the effect size (f2), for Visionary Leadership (KV) on Teachers Technology Integration (PT) was 0.060 ( small effect), and effect size (f2) for Systemic Improvement (PS) on Teachers' Technology Integration (PT) was 0.034(big effect). 


\section{DISCUSSION}

Overall, this study found that the level of Principals' Technology Leadership in National Secondary Schools in the northern region of Kedah was at a high level. This is in line with Wei, Piaw, Kannan (2017); Alkrdem (2014) and Fisher and Waller (2013). The findings also supported Papa (2011) who proposed that school principals are the crucial driving force for technology integration in schools. This study also supported and contributed to Arafeh's Integrated Technology Leadership Model (Haynes, Arafeh, \& McDaniels, 2014), which serves as a guide for orienteering new and seasoned educational leaders to the responsibilities of educational technology leadership in schools. On the other hand, findings of this study contradicted Hamzah, Juraime, Hamid and Attan (2014), who found that the level of technology leadership was at a moderate level at high performing schools in the southern region of Malaysia. The findings also supported Esplin (2017), who posited that school principals were not ready to be technology leaders.

Teachers' Technology Integration was also found to be at a high level at the corresponding schools as the principals. This was in line with Al-Jaraideh (2009) whose research findings showed that technology integration was at a high level in Jordanian classrooms. Furthermore, Hew and Tan (2016) proved that technology was integrated at a high level at 16 Organisation for Economic Co-operation and Development (OECD) countries who participated in Programme for International Student Assessment, PISA (2012). The results were consistent with Almekhlafi and Almeqdadi (2010) who reported that technology was integrated at high levels in classrooms in the United Arab Emirates.

On the contrary, this research finding also showed that the five constructs of the ISTE Standards for Administrators (2014) did not have a positive effect on Teachers' Technology Integration in $21^{\text {st }}$ century classrooms at National Secondary Schools in the northern region of Kedah. The finding supports Lafont (2011) that Teacher's Technology Integration cannot be predicted by the Principal's Technology Leadership. This finding is also in line with Page-Jones (2008) who proved that there is no relationship between technology leadership and the use of technology by teachers in schools.

\section{CONCLUSION}

Although the findings of this research showed that the levels of Technology Leadership; the five constructs of ISTE and Teachers' Technology Integration were at high levels, there was no significant relationship between Principals' Technology Leadership and Teachers' Technology Integration in the selected schools in the northern region of Kedah. Future principals' preparatory programmes should emphasize leadership based on technology to enhance school leaders confidence in using technology and integrate ICT in classrooms. Continuous professional development that have been designed for principals and teachers under the Malaysian government policies such as the Malaysia Education Blueprint (MOE, 2013), and programmes such as the School Transformation 2025 should be further improved to suit $21^{\text {st }}$ century education. These findings suggest 
that further research needs to be done on effective Technology Leadership and ICT training programmes for school principals and trainee teachers to prepare for the inevitable I.R. 4.0. Professional development for principals should be designed so that they can not only be exemplary models but have the ability to supervise Teachers' Technology Integration. Teachers must be innovative to integrate IoT in the classrooms in order to make $21 \mathrm{st}$ century education a reality and they must continue to accommodate the needs of $\mathrm{Z}$ generation students. Teachers have to attend more professional development programmes organized by Education Departments or enroll in postgraduate programmes to constructively up skill themselves in related ICT competencies and content knowledge in order to be able to function as an agent of technological change as envisaged in the Malaysia Education Blueprint (2013-2025).

These findings, however, have several limitations. Since the PTLA is a self-reporting questionnaire, it is possible that principals overrated or underrated their technology leadership standards. Despite the inaccuracy, this study will still be useful as a worthy point of reference for policy makers in effectively planning, designing and providing professional development for the present pool of principals in national secondary schools. In addition, principal preparatory training and programmes should emphasize the use of 21 st century knowledge pedagogical skills and leadership style such as the Technology Leadership to enhance and hasten the implementation of ICT for more effective teaching and learning in the classroom. Since this study was only carried out in the northern region of the state of Kedah, further research must be carried out in other regions in the state to enable more conclusive data to be obtained. This study was carried out as a cross-sectional study and data was collected in two months. It is thus recommended that a longitudinal study be carried out so that more comprehensive findings can be drawn.

\section{REFERENCES}

Albion, P. (2006). Technology leadership. Paper presented at the 17th international Conference of the Society for Information Technology \& Teacher Education, Orlando.

Al-Jaraideh, Y. A. (2009). Factors affecting information and communication technology (ICT) integration in Jordanian secondary schools. (Unpublished Doctoral dissertation). Universiti Utara Malaysia, Kedah.

Alkrdem, M. (2014). Technological leadership behaviour of high school head teachers in Asir Region, Saudi Arabia. Journal of International Education Research, 10(2), 95100. http://dx.doi.org/10.19030/jier.v10i2.8510.

Almekhlafi, A. G., \& Almeqdadi, F. A. (2010). Teachers' perceptions of technology integration in the United Arab Emirates school classrooms. Journal of Educational Technology \& Society, 13(1), 165-175.

Anderson, R., \& Dexter, S. (2005). School technology leadership: An empirical investigation of prevalence and effect. Educ. Administration Quarterly, 41(1), 49-82.

Battons, C. (2018). How IoT is changing education and learning. Retrieved from https://dzone.com/articles/how-iot-is-changing-education-and-learning-positiv. 
BestariNet School. Retrieved from http://www.beritasemasa.com.my/project-1bestarinet-yes.

Billheimer, D. M. (2007). A study of West Virginia principals: Technology standards, professional development, and effective instructional technology leaders (Doctoral disertation, Marshall University Graduate College). Retrieved from http://citeseerx.ist.psu.edu/viewdoc/download?doi=10.1.1.886.4542\&rep=rep1\&type=p df.

Brislin, R. W., \& Triandis, H. C. (1980). Handbook of cross-cultural-psychology: Social psychology. Needham Heights, MA: Allyn \& Bacon.

Brockmeier, L., Sermon, J., \& Hope, W. (2005). Principals' relationship with computer technology. NASSP Bulletin, 89(643), 45-63.

Byrom, E., \& Bingham, M. (2001). Factors influencing the effective use of technology for teaching and learning: Lessons learnt from the SEIR*TEC intensive site schools. Greensboro, NC: University of North Carolina.

Chang, I. H. (2012). The effect of principals' technological leadership on teachers' technological literacy and teaching effectiveness in Taiwanese elementary schools. Educational Technology \& Society, 15(2), 328-340.

Chin, W. W. (1998). The Partial Least Squares Approach to Structural Equation Modeling. In G. A. Marcoulides (Eds.), Modern methods for business research (pp. 295-336). Mahwah, NJ: Lawrence Erlbaum Associates.

Chin, W. W. (2010, 2017). How to write up and report PLS analyses. In V. E. Vinzi, W. W. Chi, J. Henseler, \& H. Wang (Eds.), Handbook of partial least squares concept, methods and applications (pp. 655-690). Berlin: Springer.

Davies, P. M. (2010). On school educational technology leadership. Management in Education, 24(2), 55-61. doi:10.1177/0892020610363089.

Elliott, A. C. \& Woodward, W. A. (2007). Statistical analysis quick reference guidebook Thousand Oaks, CA: SAGE Publications. doi: 10.4135/9781412985949.

Esplin, N. (2017). Utah elementary school principals' preparation as technology leaders (Unpublished doctoral dissertation). Utah State University, USA. Retrieved from https://digitalcommons.usu.edu/etd/5774.

Falk, R. F., \& Miller, N. B. (1992). A primer for soft modeling. Ohio, US: University of Akron Press.

Fisher, D. M., \& Waller, L. R. (2013). The 21st century principal: A study of technology leadership and technology integration in Texas K-12 schools. The Global E Learning Journal Volume, 2(4), 1-44.

Flanagan, L. \& Jacobsen, M. (2003). Technology leadership for the twenty-first century principal. Journal of Educational Administration, 41(2), 124-42. 
Fong, S., Ch'ng, P., \& Por, F. (2013). Development of ICT competency standard using the Delphi technique. Procedia-Social and Behavioral Sciences, 103, 299-314. http://dx.doi.org/10.1016/j.sbspro.2013.10.338.

Ford, J. I. (2000). Identifying technology leadership competencies for Nebraska's K-12 technology leaders (Unpublished doctoral dissertation). University of NebraskaLincoln, Nebraska.

Gibson, I. W. (2001). At the intersection of technology and pedagogy: Considering styles of learning and teaching. J. of Inform. Tech. for Teacher Educ., 10(1-2), 37-61.

Gotz, O., Liehr-Gobbers, K., \& Krafft, M. (2010). Evaluation of structural equation models using the partial least squares (PLS) approach. In V. E. Vinzi, W. W. Chin, J. Henseler, \& H. Wang (Eds.), Handbook of partial least squares concept, methods and applications (pp. 691-711). Berlin Heidelberg: Springer.

Gupta, P. (2016). Roles and responsibilities of a school leader in technology integration. Retrieved from http://edtechreview.in/trends-insights/insights/2541-role-ofschool-leader-principal-in-school-technology.

Hair, J. F., Black, W.C., Babin, B.J., \& Anderson, R.E. (2010). Multivariate data analysis. Upper Saddle River, New Jersey: Prentice Hall.

Hair, J. F., Hult, G. T. M., Ringle, C. M., \& Sarstedt, M. (2017). A primer on partial least squares structural equation modeling (PLS-SEM. Thousand Oaks, CA: Sage.

Harrison, C., Comber, C., Fisher, T., Haw, K., Lewin, C., Lunzer, E., et al. (2002). Impact 2: The impact of information and communication technologies on pupil learning and attainment. Retrieved from http://www.becta.org/uk/page_documents/research/Impact2_strand1 report.pdf.

Haynes, N. M., Arafeh, S., \& McDaniels, C. (2014). Educational Leadership: Perspectives on preparation and practice. Maryland: University Press of America.

Hennessy, S., Ruthven, K., \& Brindley, S. (2005). Teacher perspectives on integrating ICT into subject teaching: commitment, constraints, caution, and change. Journal of Curriculum Studies, 37(2), 155-192.

Henseler, J. F., Ringle, C. M., \& Sinkovics, R. R. (2009). The use of partial least square modeling in international marketing. New Challenges to International Marketing Advances in International Marketing, 20, 277-319.

Hew, K., \& Tan, C. (2016). Predictors of information technology integration in secondary schools: Evidence from a large-scale study of more than 30,000 Students. PLOS ONE, 11(12), 1-20. http://dx.doi.org/10.1371/journal.pone.0168547.

International Society for Technology in Education (ISTE). (July 1, 2014). ISTE standards administrators. Retrieved from http://www.iste.org/standards.

International Society for Technology in Education. (2002b). National education technology project. Retrieved from http://cnets.iste.org/creditshtml. 
International Society for Technology in Education. (2009). National education technology standards for administrators. Retrieved from http://www.iste.org/ docs/pdfs/nets-a-standards.pdf.

Jamieson-Proctor, R., Watson, G. \& Finger, G. (2003). Information and communication technologies (ICTs) curriculum integration performance measurement. Report on the development of an ICT curriculum integration performance measurement instrument. Brisbane, Australia: Griffith University.

Jamieson-Proctor, R., Watson, G., Finger, G., \& Grimbeek, P.M. (2005). An external evaluation of education Queensland's ICT curriculum integration performance measurement instrument. Brisbane, Qld: Griffith University.

Jamieson-Proctor, R., Finger, G., \& Albion, P. (2010). Auditing the TPACK capabilities of final year teacher education students: Are they ready for the 21st century? Proceedings of the 2010 Australian Computers in Education Conference (ACEC 2010) (pp. 1-12). Australian Council for Computers in Education.

Jimenez, E., Nguyen, V., \& Patrinos, H. A. (November, 2012). Stuck in the Middle? Human Capital development and economic growth in Malaysia and Thailand. Policy research working paper 6283.

Lafont, S. L. B. (2011). The relationship between principals' technology leadership and the teachers' use of technology. South eastern Louisiana University.

Leong, M. W. (2010). Principal technology leadership and the level of ICT application of teachers at a secondary school in Seremban district. (Unpublished master thesis). University of Malaya, Kuala Lumpur.

$\mathrm{Lu}, \mathrm{H}$. Y. (2013). Technology integration and pedagogical innovations in Malaysia Higher Education Institutions. (Unpublished doctoral dissertation). University of Malaya, Kuala Lumpur.

Marzano, R.J., Waters, T., \& McNulty, B.A. (2005). School leadership that works: From research to results. Alexandria, VA: Association for Supervision and Curriculum Development.

McLeod, S., \& Richardson, J. W. (2011). The dearth of technology coverage. Journal of School Leadership, 21 (2), 216-240.

Metcalf, W. B. (2012). K-12 principals' perceptions of their technology leadership preparedness (Unpublished doctoral dissertation). Georgia Southern University, Statesboro, GA. Retrieved from https://digitalcommons.georgiasouthern.edu/cgi/viewcontent.cgi?article=1400\&context= etd.

Moidunny, K. (2009). The effectiveness of the national professional qualifications for educational leaders (NPQEL) (Unpublished doctoral dissertation). Universiti Kebangsaan Malaysia, Bangi. 
Ministry of Education (2012). Interim strategic plan 2011-2020 [Pdf document]. Retrieved from www.moe.gov.my/bppdp.

Ministry of Education. (2012). National education policy. Retrieved from https://www.moe.gov.my.

Ministry of Education. (2012). Educational policy planning and revision division. Retrieved from https://www.moe.gov.my.

Ministry of Education (2013.) Malaysia education blueprint, 2013-2025. Putrajaya: Ministry of Education.

Ministry of Finance. (2014). Retrieved from https://www.researchgate.net/...Malaysia/.../ $57 \mathrm{e} 20 \mathrm{c} 3808 \mathrm{aed} 96 \mathrm{fbbb}$

Mullen, C. (2019). (2019, May 1). 21st-century priorities for leadership education and prospective school leaders. Retrieved from https://www.researchgate.net/publication/331718834_21 ${ }^{\text {st }}$ Century_Priorities_for_Leader ship_Education_and_Prospective_School_Leaders.

National Audit Department. (2014). Keberkesanan program kelayakan profesional pemimpin pendidikan kebangsaan (NPQEL) ambilan 1 tahun 2013. Jabatan Pembangunan Pengurus, Pemimpin dan Eksekutif Pendidikan (JPPPEP). Genting Highlands: Institut Aminuddin Baki.

Nunnally, J. C. (1978). Psychometric theory. New York: McGraw-Hill.

Page-Jones, A. B. (2008). Leadership behavior and technology activities: The relationship between principals and technology use in schools (Unpublished doctoral dissertation). University of Central Florida Orlando, Florida.

Papa, R. (2011). Technology leadership for school improvement. Thousand Oaks: Sage.

Richardson, W. (2012). Preparing students to learn without us. Educational Leadership, 69(5), 22-26.

Richardson, J. W., Bathon, J., Flora, K. L., \& Lewis, W. D. (2012). NETS-A scholarship: A review of published literature. Journal of Research on Technology in Education, 45(2), 131-151. https://doi.org/10.1080/15391523.2012.10782600.

Scott, G. (2005). Educator perceptions of principal technology leadership competencies (Unpublished doctoral dissertation). The University of Oklahoma, Oklahoma.

Ringstaff, C., \& Kelley, L. (2002). The learning return on our educational technology investment: A review of findings from research [Pdf Document]. Retrieved from http://www.wested.org/online_pubs/learning_return.pdf.

Robinson, J. P., Shaver, P. R., \& Wrightsman, L. S. (1991). Measures of personality and social psychological Attitudes. New York, NY: Academic Press. 
Roblyer, M., \& Doering, A. (2014). Integrating educational technology into teaching. Harlow: Pearson.

Schwab, K., \& Davis, N. (2018). Shaping the fourth industrial revolution. New York: Crown Publishing Group.

Senge, P. M. (1990). The fifth discipline. The art and practice of the learning organization. London, England: Random House.

Sincar, M. (2013). Challenges school principals facing in the context of technology leadership. Educational Sciences: Theory \& Practice, 13(2), 1273-1284.

Solomon, G. (1995). Planning for technology. Learn. \& Lead. with Tech., 23(1), 66-67.

Wahdain, E. A., \& Ahmad, M. N. (2014). User acceptance of Information Technology: Factors, theories and applications. J. of Inform. Systems Res. and Innovation, 6, 17-25.

Wei, L. M., Piaw, C. Y., \& Kannan, S. (2017). Relationship between principal technology leadership practices and teacher ICT competency. MOJEM: Malaysian Online Journal of Educational Management, 4(3), 13-36.

Wei, L. M., Piaw, C. Y., Kannan, S., \& Moulod, S. A. (2016). Relationship between teacher ICT Competency and teacher acceptance and use of school management system (SMS). Malaysian Online Journal of Educational Technology, 4(4), 36-52. 